\title{
Pengaruh Model Pembelajaran dan Gaya Belajar terhadap Keterampilan Proses Sains Peserta Didik Kelas VII SMP Negeri 30 Makassar
}

\author{
Mutahharah Hasyim, Muris, Ahmad Yani \\ Pendidikan Fisika PPs Universitas Negeri Makassar \\ Surat-e: mutahharah_hasyim@yahoo.com
}

\begin{abstract}
Penelitian ini merupakan penelitian eksperimen yang bertujuan untuk mengetahui perbedaan keterampilan proses sains antara model pembelajaran langsung dan pembelajaran konvensional ditinjau dari gaya belajar yang dimiliki peserta didik baik audio-visual maupun kinestetik dan interaksi antara model pembelajaran dan gaya belajar terhadap keterampilan proses sains pada peserta didik kelas VII SMP Negeri 30 Makassar. Desain penelitian yang digunakan adalah desain faktorial $2 \times 2$. Pengujian hipotesis dilakukan dengan menggunakan analisis varians dua arah GLM Univariat yang dilanjutkan dengan Uji Tukey dan Scheffe dengan menggunakan program SPSS versi 20.0 for windows dengan taraf signifikansi $5 \%$. Hasil penelitian ini menunjukkan bahwa (I) terdapat perbedaan keterampilan proses sains antara peserta didik yang diajar dengan model pembelajaran langsung dengan peserta didik yang diajar dengan menggunaan pembelajaran konvensional ; (2) tidak terdapat perbedaan keterampilan proses sains antara peserta didik yang memiliki gaya belajar audio-visual dengan peserta didik yang memiliki gaya belajar kinestetik; dan (3) terdapat interaksi antara model pembelajaran dan gaya belajar (audio-visual dan kinestetik) terhadap keterampilan proses sains peserta didik.
\end{abstract}

Kata kunci: gaya belajar, keterampilan proses sains, model pembelajaran

\section{Pendahuluan}

Mata pelajaran Fisika di Sekolah Menengah Pertama (SMP) tidak dapat dipisahkan dalam kehidupan sehari-hari karena menekankan pada pemberian pengalaman langsung tentang cara memperoleh informasi sains, cara sains dan teknologi (terapan sains) bekerja dalam wujud pengetahuan prosedural (procedural knowledge), termasuk kebiasaan bekerja ilmiah dengan menerapkan metode dan sikap ilmiah. Kemampuan bekerja secara ilmiah harus didukung oleh berkembangnya rasa ingin tahu, kemauan bekerjasama, dan peserta didik secara langsung dan aktif dalam pembelajaran melalui penggunaan dan pengembangan keterampilan proses sains (Putra, 2012).

Salah satu model pembelajaran yang sesuai untuk melatihkan keterampilan proses sains peserta didik di Sekolah Menengah Pertama (SMP) adalah model pembelajaran langsung. Model ini sangat cocok untuk mengajarkan fisika dan melatihkan keterampilan proses, karena sebagian besar materinya merupakan ilmu pengetahuan yang bersifat deklaratif dan prosedural sebagaimana tujuan yang ingin dicapai dalam model pembelajaran langsung. Melatihkan keterampilan proses sains sangat cocok dipadukan dengan model pembelajaran langsung dengan alasan bahwa dalam model pengajaran langsung terdapat fase yang menekankan adanya latihan terbimbing sehingga peserta didik dapat meminimalkan adanya kesalahan dalam melakukan praktek (demonstrasi).

Kualitas suatu keberhasilan dalam pembelajaran dapat dilihat dari hasil yang diperoleh peserta didik setelah pembelajaran. Dalam proses pencapaiannya dipengaruhi oleh berbagai faktor. Salah satu faktor yang dianggap berpengaruh dalam kegiatan pembelajaran adalah gaya belajar. Gaya belajar yang dimaksud meliputi gaya belajar visual, auditori, dan kinestetik.

Penelitian ini bertujuan untuk mengetahui ada tidaknya perbedaan keterampilan proses sains pada peserta didik yang diajar dengan model pembelajaran langsung dengan peserta didik yang diajar secara konvensional ditinjau dari gaya 
belajarnya (audio-visual dan kinestetik) dan ada tidaknya interaksi antara model pembelajaran dan gaya belajar pada keterampilan proses sains peserta didik kelas VII SMP Negeri 30 Makassar.

\section{Landasan Teori}

\section{Model Pembelajaran Langsung}

Model pembelajaran pada dasarnya merupakan petunjuk bagi pendidik dalam merencanakan pembelajaran di kelas mulai dari menyediakan perangkat pembelajaran, media, sampai alat evaluasi yang mengarah pada pencapaian tujuan pembelajaran dengan meliputi adanya komponen model yaitu sintaks (fase) pembelajaran, sistem sosial, prinsip reaksi, sistem pendukung, dan efek instruksional dan pengiring.

Model pembelajaran langsung dirancang khusus untuk mengembangkan aktivitas sains peserta didik tentang pengetahuan prosedural dan pengetahuan deklaratif yang terstruktur dengan baik dan dapat dipelajari selangkah demi selangkah (Kardi, 2000).

Tahapan pembelajaran langsung dapat digambarkan dalam sebuah skema berikut (Reigeluth, 2009).

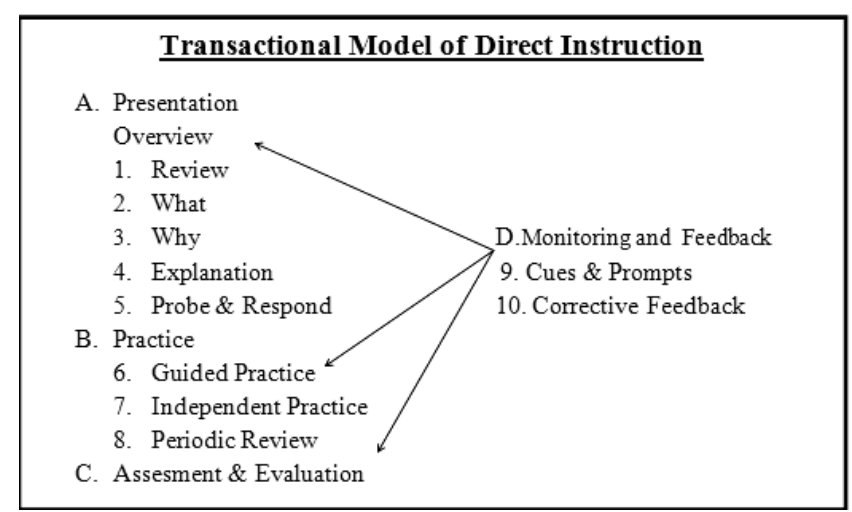

Gambar I Skema Pembelajaran DI William. G. Huitt, dkk

\section{Gaya Belajar}

Gaya belajar merupakan sebuah pendekatan yang menjelaskan mengenai bagaimaa individu untuk berkonsentrasi pada proses, dan menguasai informasi yang sulit dan baru melalui persepsi yang berbeda (Ghufron, 20I2).

Gaya belajar terdiri atas tiga yaitu; (I) Gaya belajar visual (V) yang cenderung lebih dominan dalam penglihatannya dibanding dengan pendengaran dan gerakan-gerakannya. Orang yang memiliki gaya belajar seperti ini cenderung lebih khusus dalam belajar dengan selalu melihat pada fokus telaahannya; (2) Gaya belajar auditorial (A). Orang auditorial dalam belajar lebih memfokuskan pada apa yang mereka dengar; (3) Gaya belajar kinestetik (K) adalah orang yang memiliki gaya belajar melalui gerak dan sentuhan (DePorter, 2003). Anak usia sekolah yang paling memiliki kekuatan modalitas gaya belajar terbesar adalah anak yang memiliki gaya belajar visual sebesar $30 \%$, kemudian diikuti oleh anak yang memiliki gaya belajar auditori sebesar $25 \%$, dan kemudian gaya belajar kinestetik sebesar $15 \%$ (Gilakjani, 20I2).

\section{Keterampilan Proses Sains}

Keterampilan Proses Sains merupakan pendekatan dalam pembelajaran Sains yang sangat penting karena berkaitan dengan pengalaman langsung. Pengalaman langsung dapat dilihat melalui pengamatan dan kontak langsung dengan alam sekitar yang menjadi objek belajar (Sukarno, dkk, 2013).

Keterampilan proses sains yang dilatihkan untuk peserta didik SMP meliputi mengamati, merumuskan masalah dan hipotesis, merancang percobaan, menganalisis data, komunikasi, dan menyimpulkan.

\section{Metode Penelitian}

\section{Jenis dan Desain Penelitian}

Penelitian ini adalah penelitian eksperimen dengan desain yang digunakan yaitu factorial design dengan desain sebagai berikut $[9]$.

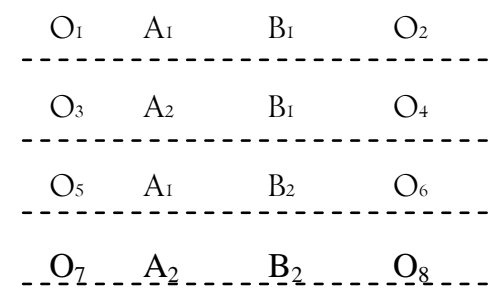

Gambar 2 Desain Faktorial

Rancangan faktorial $2 \times 2$ yang digunakan ditunjukkan pada Tabel I berikut (Subana, 20II).

Tabel I. Tabel Desain Faktorial 2x2

\begin{tabular}{lll}
\hline \multirow{2}{*}{$\begin{array}{l}\text { Gaya Belajar } \\
\left(\mathrm{B}_{\mathrm{I}}\right)\end{array}$} & \multicolumn{3}{l}{ Model Pembelajaran $(\mathrm{A})$} \\
\cline { 2 - 3 } & $\mathrm{AI}$ & $\mathrm{A}_{2}$ \\
\hline $\mathrm{B}_{\mathrm{I}}$ & $\mathrm{YA}_{\mathrm{I}} \mathrm{B}_{\mathrm{I}}$ & $\mathrm{YA}_{2} \mathrm{~B}_{\mathrm{I}}$ \\
\hline
\end{tabular}




\begin{tabular}{lll}
\hline $\mathrm{B}_{2}$ & $\mathrm{YA}_{1} \mathrm{~B}_{2}$ & $\mathrm{YA}_{2} \mathrm{~B}_{2}$ \\
\hline Total & $\mathrm{YA}_{1} \mathrm{~B}_{1}+\mathrm{YA}_{1} \mathrm{~B}_{2}$ & $\mathrm{YA}_{2} \mathrm{~B}_{1}+\mathrm{YA}_{2} \mathrm{~B}_{2}$ \\
\hline
\end{tabular}

\section{Variabel dan Definisi Operasional Variabel}

Variabel dalam penelitian ini terdiri dari variabel bebas yaitu model pembelajaran (A) yang atas model pembelajaran langsung $\left(\mathrm{A}_{\mathrm{I}}\right)$ dan pembelajaran secara konvensional $\left(\mathrm{A}_{2}\right)$, variabel terikat yaitu keterampilan proses sains, dan variabel moderator yaitu gaya belajar (B) yang terdiri atas dua dimensi yaitu: gaya belajar audio-visual $\left(\mathrm{B}_{\mathrm{I}}\right)$ dan kinestetik $\left(\mathrm{B}_{2}\right)$.

Untuk definisi operasional penelitian ini adalah:

I. Model Pembelajaran Langsung adalah pedoman pembelajaran yang dirancang untuk meningkatkan penguasaan berbagai keterampilan (pengetahuan prosedural dan pengetahuan konseptual) dan dapat dipelajari selangkah demi.

2. Pembelajaran secara konvensional adalah pembelajaran yang digunakan oleh pendidik di SMP Negeri 30 Makassar yaitu menggunakan model koperatif tipe STAD.

3. Gaya belajar adalah cara yang cenderung dipilih seseorang dalam menyerap dan mengatur serta mengolah informasi dengan mudah dari lingkungan.

Keterampilan Proses Sains adalah keterampilan yang menjadikan sains sebagai pendekatan dalam proses belajar mengajar dilakukan untuk mendapatkan pengetahuan dengan menggunakan pengamatan dan eksperimen dan dibuktikan melalui metode ilmiah.

\section{Populasi dan Sampel}

Populasi pada penelitian ini adalah seluruh peserta didik kelas VII SMP Negeri 30 Makassar berjumlah 360 orang. Sedangkan pengambilan sampel dilakukan dengan teknik pengacakan kelas dengan asumsi bahwa semua kelas homogen. Oleh karena itu dipilih sampel yaitu Kelas $\mathrm{VII}_{3}$ dan Kelas VIIs yang masing-masing terdiri dari 40 orang.

\section{Jenis dan Desain Penelitian}

Teknik pengolahan data menggunakan análisis deskriptif dan analisis inferensial. Analisis deskriptif digunakan untuk mendeskripsikan keterampilan proses peserta didik. Sedangkan análisis inferensial digunakan untuk menguji hipotesis. Namun terlebih dahulu dilakukan pengujian normalitas dan pengujian homogenitas. Analisis data untuk menguji hipotesis efek utama (main effect) dapat dilakukan melalui Analysis of Varians (ANOVA) dengan bantuan software SPSS 20 for Windows (Subana, 201 I).

Tabel 2. Tabel Ringkasan Anava Dua Jalur

\begin{tabular}{|c|c|c|c|c|}
\hline $\begin{array}{l}\text { Sumber Variansi } \\
\quad(\mathrm{SV})\end{array}$ & $\begin{array}{l}\text { Jumlah } \\
\text { Kuadrat } \\
\text { (JK) }\end{array}$ & $\begin{array}{l}\text { Derajat } \\
\text { Kebebasan } \\
\text { (db) }\end{array}$ & $\begin{array}{c}\text { Rerat } \\
\text { a } \\
\text { Kuadrat } \\
\text { (RK) }\end{array}$ & $\mathrm{F}$ \\
\hline Rata-rata baris & $\mathrm{JK}_{\mathrm{A}}$ & b-I & $\mathrm{RK}_{\mathrm{A}}$ & $\mathrm{F}$ \\
\hline Rata-rata kolom & $\mathrm{JK}_{\mathrm{B}}$ & $\mathrm{k}-\mathrm{I}$ & $\mathrm{RK}_{\mathrm{B}}$ & $\mathrm{F}$ \\
\hline Interaksi & $\mathrm{JK}_{\mathrm{AB}}$ & I) $(\mathrm{b}-\mathrm{I})(\mathrm{k}-$ & $\mathrm{RK}_{\mathrm{AB}}$ & $\mathrm{F}$ \\
\hline Error (D) & $\mathrm{JK}_{\mathrm{D}}$ & $\mathrm{bk}(\mathrm{n}-\mathrm{I})$ & $\mathrm{RK}_{\mathrm{D}}$ & \\
\hline Total & $\mathrm{JK}_{\mathrm{T}}$ & bkn - I & $\mathrm{RK}_{\mathrm{T}}$ & \\
\hline
\end{tabular}

\section{Hasil dan Pembahasan}

\section{Perbandingan tingkat keterampilan Proses Sains}

Perbandingan tingkat keterampilan proses sains pada kedua kelompok pembelajaran dapat dilihat pada 3.

Tabel 3. Tingkat Keterampilan Proses Sains Peserta didik kelas DI dan kelas Konvensional

\begin{tabular}{|c|c|c|c|c|c|}
\hline No & Indikator KPS & $\begin{array}{l}\text { Kelas } \\
\text { Pembe- } \\
\text { lajaran } \\
\text { DI }\end{array}$ & $\begin{array}{l}\text { Kate- } \\
\text { gori }\end{array}$ & $\begin{array}{l}\text { Kelas } \\
\text { Pembelajaran } \\
\text { Konvensional }\end{array}$ & $\begin{array}{l}\text { Kete- } \\
\text { gori }\end{array}$ \\
\hline I & $\begin{array}{l}\text { Melakukan } \\
\text { pengamatan }\end{array}$ & 78,00 & $\mathrm{~T}$ & 76,00 & $\mathrm{~T}$ \\
\hline 2 & $\begin{array}{l}\text { Merumuskan } \\
\text { masalah }\end{array}$ & 63,16 & $\mathrm{~T}$ & 56,58 & S \\
\hline 3 & $\begin{array}{l}\text { Merumuskan } \\
\text { hipotesis }\end{array}$ & 64,47 & $\mathrm{~T}$ & $4 \mathrm{I}, 45$ & S \\
\hline 4 & $\begin{array}{l}\text { Merancang } \\
\text { percobaan }\end{array}$ & 66,00 & $\mathrm{~T}$ & 64,00 & $\mathrm{~T}$ \\
\hline 5 & Menganalisis data & 82,00 & ST & $7 \mathrm{I}, 58$ & $\mathrm{~T}$ \\
\hline 6 & $\begin{array}{l}\text { Mengkomunikasi } \\
\text { kan }\end{array}$ & 56,00 & S & 53,00 & S \\
\hline 7 & Menyimpulkan & 63,00 & $\mathrm{~T}$ & 63,16 & $\mathrm{~T}$ \\
\hline
\end{tabular}

Keterangan: $\quad 0<\mathrm{X} \leq 20$ berarti Sangat Rendah (SR) $2 \mathrm{I}<\mathrm{X} \leq 40$ berarti Rendah $(\mathrm{R})$ $4 \mathrm{I}<\mathrm{X} \leq 60$ berarti Sedang $(\mathrm{S})$ $6 \mathrm{I}<\mathrm{X} \leq 80$ berarti Tinggi $(\mathrm{T})$ $8 \mathrm{I}<\mathrm{X} \leq \mathrm{IOO}$ berarti Sangat Tinggi $(\mathrm{ST})$

\section{Analisis Deskriptif Keterampilan Proses Sains}


Keterampilan proses sains peserta didik dinilai pada saat proses pembelajaran berlangsung dan pemberian tes dilakukan setelah pembelajaran di akhir pertemuan selesai. Skor statistik deskriptif untuk keterampilan proses sains peserta didik pada kedua kelompok pembelajaran dapat dilihat pada tabel 4 .

Tabel 4. Skor statistik deskriptif Keterampilan Proses Sains

\begin{tabular}{lcc}
\hline \multirow{2}{*}{ Statistik } & \multicolumn{2}{c}{ Kelompok Perlakuan } \\
\cline { 2 - 3 } & $\begin{array}{c}\text { Model } \\
\text { Pembelajaran DI }\end{array}$ & $\begin{array}{c}\text { Pembelajaran } \\
\text { Konvensional }\end{array}$ \\
\hline Banyak Sampel & 38 & 38 \\
Mean & 34,50 & 31,97 \\
Standar Deviasi & 4,37 & 3,42 \\
Variansi & 19,12 & 11,75 \\
Maksimum & 46,00 & 39,00 \\
Minimum & 25,00 & 24,00 \\
Skor Ideal & 50,00 & 50,00 \\
\hline
\end{tabular}

\section{Pengujian Normalitas}

Hasil pengujian normalitas terhadap keterampilan proses sains fisika pada kedua kelompok pembelajaran adalah sebagai berikut:

Hasil uji normalitas tes keterampilan proses sains fisika pada kelompok eksperimen I diperoleh nilai $\times 2$ hitung $=\mathrm{I}$, 92.

Dengan $\alpha=0,05$ dan $\mathrm{dk}=(\mathrm{k}-\mathrm{I})=2$ diperoleh nilai $\mathrm{x} 2$ tabel $=5$, 99. Karena $\mathrm{x} 2$ hitung $<\mathrm{x} 2$ tabel, maka dapat disimpulkan bahwa data tes keterampilan proses sains fisika kelompok eksperimen I dinyatakan berdistribusi normal.

Hasil uji normalitas tes keterampilan proses sains fisika pada kelas eksperimen II diperoleh nilai $\mathrm{x} 2$ hitung $=2,65$. Dengan $\alpha=0,05$ dan $\mathrm{dk}=(\mathrm{k}-\mathrm{I})=2$ diperoleh nilai $\mathrm{x} 2$ tabel $=5$, 99. Karena $\mathrm{x} 2$ hitung $<\mathrm{x} 2$ tabel, maka dapat disimpulkan bahwa data tes keterampilan proses sains fisika untuk kelompok eksperimen II dinyatakan berdistribusi normal.

\section{Pengujian Homogenitas}

Berdasarkan hasil pengujian homogenitas tes keterampilan proses sains fisika pada kelas eksperimen I dan kelas eksperimen II diperoleh nilai Fhitung $=$ I,63 dengan taraf kesalahan $\alpha=0,05$ diperoleh harga Ftabel $=3, \mathrm{I} 2$. Karena Fhitung $(1,63)<$ Ftabel $(3,12)$ maka kedua pembelajaran tersebut dinyatakan homogen.

\section{Pengujian Hipotesis}

Pengujian hipotesis statistik $\mathrm{Ho}: \mu 0=\mu$

$\mathrm{HI}: \mu 0 \neq \mu$
Hasil analisis data dengan ANAVA dua jalur dari tes Keterampilan Proses Sains peserta didik dalam penelitian ini diperoleh output dengan bantuan SPSS 20.0 for windows. Adapun hasil analisis ANAVA dua jalur pada tabel 5.

Tabel 5. Hasil analisis ANAVA dua jalur Tests of Between-Subjects Effects

\begin{tabular}{lrrrrr}
\hline Dependent Variable: KPS & $\begin{array}{c}\text { Type III Sum of } \\
\text { Squares }\end{array}$ & df & $\begin{array}{l}\text { Mean } \\
\text { Square }\end{array}$ & F & Sig. \\
\hline $\begin{array}{l}\text { Corrected } \\
\text { Model }\end{array}$ & $182.344^{\mathrm{a}}$ & 3 & 60.781 & 4.047 & .010 \\
\hline Intercept & 46953.488 & 1 & 46953.488 & 3126.200 & .000 \\
\hline Model & 180.208 & 1 & 180.208 & $\mathbf{1 1 . 9 9 8}$ & $\mathbf{. 0 0 1}$ \\
\hline Gaya & 1.412 & 1 & 1.412 & $\mathbf{. 0 9 4}$ & $\mathbf{. 7 6 0}$ \\
\hline Model * Gaya & 60.571 & 1 & 60.571 & $\mathbf{4 . 0 3 3}$ & $\mathbf{. 0 4 8}$ \\
\hline Error & 1081.393 & 72 & 15.019 & & \\
\hline Total & 85220.000 & 76 & & & \\
\hline Corrected Total & 1263.737 & 75 & & & \\
\hline \multicolumn{5}{c}{}
\end{tabular}

Pada penelitian ini, ada dua kelompok peserta didik yang diajar menggunakan model pembelajaran yang berbeda yaitu; (I) kelompok yang memiliki gaya belajar audio-visual dan (2) kelompok yang memiliki gaya belajar kinestetik. Untuk hipotesis pertama HO ditolak dan HI diterima. Hal ini terlihat dari hasil perhitungan ANAVA dua jalur dengan menggunakan program SPSS 20.0 for windows yang menunjukkan Fhitung $<$ Ftabel yaitu II,998 > 3,970, maka untuk hipotesis pertama $\mathrm{HO}$ ditolak.

Berdasarkan hasil analisis data untuk mengetahui perbedaan kelompok peserta didik yang memiliki gaya belajar audio-visual dan kinestetik terhadap Keterampilan Proses Sains pada peserta didik diperoleh skor Fhitung sebesar 0,094 dan Ftabel sebesar 3,970. Hasil ini menunjukkan Fhitung $<$ Ftabel. Begitu pula dengan nilai signifikansi yang diperoleh sebesr $0,760>0,05$, artinya untuk hipotesis kedua $\mathrm{HO}$ diterima.

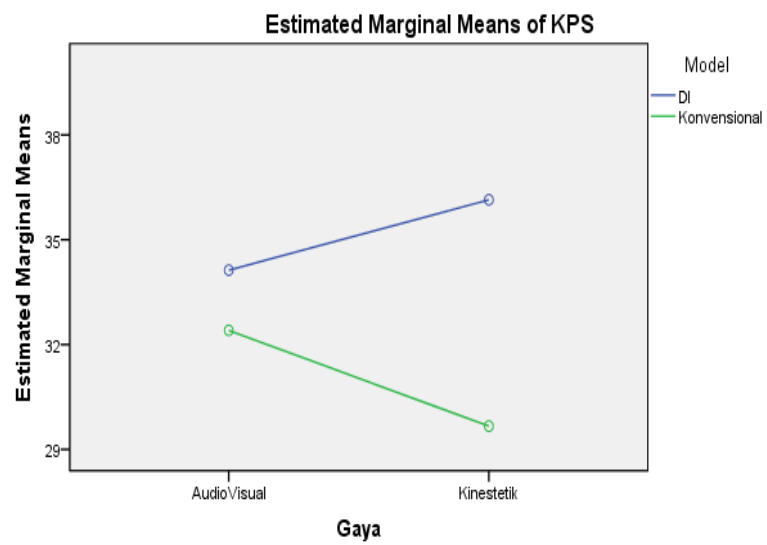

Gambar 3. Interaksi ntara model pembelajaran dan gaya belajar terhadap keterampilan proses sains 
Hasil analisis data interaksi menunjukkan untuk Fhitung sebesar 4,033 dan Ftabel sebesar 3,970. Hasil ini menunjukkan Fhitung $>$ Ftabel. Begitu pula dengan nilai signifikansi yang diperoleh sebesr 0,048<0,05, artinya untuk hipotesis ketiga HO ditolak. Hasil analisis ini menunjukkan bahwa terdapat interaksi antara model pembelajaran dan gaya belajar terhadap keterampilan proses sains peserta didik. Model pembelajaran langsung cocok dikombinasikan dengan gaya belajar kinestetik sedangkan pembelajaran konvensional cocok dikombinasikan dengan gaya belajar audio-visual. Perhatikan gambar 3.

\section{Kesimpulan}

Berdasarkan analisis data dari hasil penelitian yang telah dilakukan, maka dapat dikemukakan kesimpulan berikut.

I. Terdapat perbedaan yang signifikan pada Keterampilan Proses Sains antara peserta didik yang diajar dengan menggunakan model pembalajaran langsung (DI) dengan peserta didik yang diajar dengan pembelajaran konvensional kelas VII SMP Negeri 30 Makassar.

2. Tidak terdapat perbedaan yang signifikan pada Keterampilan Proses Sains antara peserta didik yang memiliki gaya belajar audio- visual dengan peserta didik yang memiliki gaya belajar kinestetik kelas VII SMP negeri 30 Makassar.

3. Terdapat interaksi antara model pembelajaran dan gaya belajar terhadap Keterampilan Proses Sains pada peserta didik kelas VII SMP Negeri 30 Makassar.

\section{Ucapan Terima Kasih}

I. Bapak Prof. Dr. Jasruddin, M.Si, selaku ketua Program Pascasarjana Universitas Negeri Makassar yang senantiasa memberikan dukungan baik secara moril dan materil.

2. Bapak Prof. Dr. Muris, M.Si, selaku ketua prodi Pendidikan Fisika Program Pascasarjana Universitas Negeri Makassar atas bimbingan dan motivasi yang diberikan kepada penulis.

3. Bapak Dr. Ahmad Yani, M.Si, selaku dosen pembimbing penulis atas waktu dan motivasinya.

\section{Kepustakaan}

DePorter, Bobbi \& Hernacki, Mike. 2003. Quantum Learning (Terjemahan). Bandung : Kaifa.

Ghufron, Nur dkk. 2012. Gaya Belajar (kajian teoritik). Yogyakarta: Pustaka Pelajar.

Gilakjani, A.P. 2012. Visual, Aauditory, Kinaesthetic Learning Styles and Their Impacts on English Language Teaching. Journal of Studies in Education, 2(I), 2I 62 6952.

Kardi, S, dan Nur, M. 2000. Pengajaran Langsung. Surabaya: University Press.

Putra, S.R. 2012. Desain Belajar Mengajar Kreatif Berbasis Sains. Jogyakarta: Diva Press.

Reigeluth, Charles. 2009. Instructional Design Theories and Models, Voume III. New York. Taylor and Francis Publishers

Subana. 20II. Dasar- Dasar Penelitian Ilmiah. Bandung: Pustaka Setia

Sukarno, dkk. 2013. Science Teacher Understanding to Science Process Skills and Implications for Science Learning at Junior High School (Case Study in Jambi). International Journal of Science and Research (IJSR). India Online 2319-7064

Tuckman, B. W. I999. Conducting Educational Research. (5th Ed.). New York: Harcourt Brace College Publeshers. 